\title{
INVESTIGATION FOR REPLACEMENT OF CEMENT THROUGH WASTE GLASS POWDER IN SUSTAINABLE CONCRETE
}

\author{
Rishabh Arora, Kaushal Kumar \\ E-Mail Id: rishabh.a@krmangalam.edu.in, kaushal.kumar@krmangalam.edu.in \\ School of Engineering and Technology, K.R. Mangalam University, Gurgaon, Haryana
}

\begin{abstract}
Use of waste product (discarded item for consumption) in concrete as partial replacement of cement could be a stepping stone in development of sustainable ecofriendly materials. In this paper waste glass powder is used for the investigation regarding replacement of cement in concrete. The pozzolanic properties of fine glass powder make it suitable for application in concrete. In order to commenced the study a number of experiments has been takes place like Compressive Strength Test (CST), Slump Test (ST) and Flexural Strength Test (FST). Above mentioned tests were conducted to investigate the replacement of cement by using $10 \%$ glass powder. A set of different curing age (7 days and 28 days) is considered for the experimentation purposes. Results obtained from strength tests of the glass powder based concrete were promising and clearly indicating towards the better economic aspects of glass powder for utilization as the replacement of cement in concrete.
\end{abstract}

\section{INTRODUCTION}

Presently, material glass have applications in electronic industry by making of different screen based products like LCD, TV, Tabs, etc. Similarly in civil/construction based industry in terms of mirrors, hinged products etc. Also have applications in food or medical sector particularly from making of surgical equipment to the bottles of beverage industry [1]. As a result, glass industry has different potential approaches throughout the globe. Every product has their utilization period and after that time it is considered as waste. However, a significant amount of unusable items or defected or broken packaging glass is sent to landfill, basically acquire more useable space or land to more urgent uses [2-3]. So it is necessary for the consumable countries to prepare a better policy for utilization of these waste glasses. According to report, globally production of waste glass powder is about 130 $\mathrm{Mt}$, in which the EU (European Union) and china produces about $65 \mathrm{Mt}$ while USA produces $20 \mathrm{Mt}$ [4]. Its large production causes environmental impacts and its disposal in landfill became costly. Glass powder is widely used in different product throughout the world due to its reliability, versatility and durability.

Mainly glass products are prepared from the recycled material and also repeat this recycled process many times without changing their chemical phases or configuration [5]. The recycling of glass starts by melting a mixture containing materials such as: soda ash, silica, calcium carbonate $\left(\mathrm{CaCO}_{3}\right)$, and recycled glass pieces. Researcher reported that it can be utilized to create blended cement which improves durability, workability and economy of the concrete materials [6]. Researches point towards the better chemical behaviour of glass rather than other customary materials [7-8]. In addition, it was found that fine milling glass powder improve the reactions between glass and cement hydrates, can be utilized as additive in cement [9-11]. Many efforts have been made to use waste glass in construction industry but studies regarding the utilization of waste material like glass powder [2-12]. But the replacement cement particles in concrete through waste glass powder are very narrow.

So, an experimental investigation has been carried out with Waste Glass Powder (WGP) to produce sustainable concrete. Cube samples were prepared for compressive strength test, slump test and the flexural strength test for the mixes at the curing age of 7 days and 28 days.

\section{METHODOLOGY}

The study based on replacement of small fraction of port land cement through waste material from glass milling or WGP only. It is mandatory that the level of water content is not changed through this replacement or as it is in common concrete. The contents of this material are water, ordinary and Portland cement, aggregates and WGP. During this process proper cooling process are also utilized with testing of material to obtained desired strength. Mix design prepared after selection of optimal w/c ratio through proper mix trials. Materials are also proportionate according to the design.

\subsection{Sample Preparation and Experimentation}

The chemical composition of Waste Glass Powder (WGP) shows that it is enriched with silica, one of the main constituent of cement. For the testing purpose, mixture prepared with normal or standard proportion (M-20). The first sample was prepared or the first mix was prepared from the cement only or there was no replacement of cement with WGP. Waste Glass Powder (WGP) is used for the replacement of cement in concrete about 10\%. The Mx-1 mix represents the replacement of cement by WGP by $10 \%$. So, in Mx -0 the proportion of cement is $100 \%$ while the Mx -1 contains $90 \%$ cement and $10 \%$ WGP. Cube samples was prepare of size $150 \times 150 \times 150$ $(\mathrm{mm})$. Three samples for each test have been prepared with replacement of cement from WGP and without replacement any cement particle respectively. Firstly, concrete paste has been prepared with proper proportion of the Materials. In order to analyze the properties of prepared concrete the specimens were casted and cured prior. 
ICAASET-2021, 20-21 May, 2020, K.R. Mangalam University, Gurugram

International Journal of Technical Research \& Science (Special Issue) ISSN No.:2454-2024 (online)

Prepared sample tested for different two category primarily fresh concrete test and secondly hardened concrete tests. Primary testing includes Slump Cone test and Compaction Factor Test. On the other hand secondary testing involves Compressive Strength Test and Flexural Strength Test. Slump test has been conducted on the standards of ASTM while Compactions Factor (CF) has been determined based on IS1199:1999 standards. Similarly, Compression Strength Test (CST) performed with standards ASTME-9 while Flexural Strength Test (FST) performed with standards ASTMC-293. Average of three tests has been calculated for the Average Compression Strength (ACS) and Average Flexural Strength (AFS). For the testing purpose three samples were prepared for each set of combination for 7 days and 28 days.

\section{RESULTS AND DISCUSSIONS}

The prepared cube samples were used for the testing. The results of compaction factor and slum with 7 and 28 days compressive strength are incorporated in the table 1. It was found that with increase the amount of WGP, value of slump was increases. The value of slump found as 50 and $60 \mathrm{~mm}$ for Mx-0 and Mx1 respectively. Results indicate that value of CF is directly proportion to the amount of WGP. Result also indicating that regular or uniformity of the mixing of WGP increases the workability of the concrete.

Repetition of experiments also scheduled for the CST. It have been predicted that the Mx-1 sample have higher or maximum $\mathrm{CS}$ as compared to sample Mx-0. From the results, it was observed that CS of concrete is increases with replacement of $10 \%$ cement from WGP. It was observed that approximate $11 \%$ of CS increases with the addition of $10 \%$ of WGP in the case of 7 days while the same improvement is observed as $9 \%$ in the case of 28 days.

Table-3.1 Testing results for Compressive Strength

\begin{tabular}{|c|c|c|c|c|c|c|c|}
\hline \multirow{2}{*}{$\begin{array}{c}\text { Mix } \\
\text { Description }\end{array}$} & \multirow{2}{*}{$\begin{array}{l}\text { Slump } \\
(\mathrm{mm})\end{array}$} & \multirow{2}{*}{$\mathrm{CF}$} & \multirow{2}{*}{ Sample } & \multicolumn{2}{|c|}{ Strength After 7 days } & \multicolumn{2}{|c|}{ Strength After 28 days } \\
\hline & & & & $\mathrm{CS}\left(\mathrm{N} / \mathrm{mm}^{2}\right)$ & $\begin{array}{c}\mathrm{ACS} \\
\left(\mathrm{N} / \mathrm{mm}^{2}\right)\end{array}$ & $\begin{array}{c}\mathrm{CS} \\
\left(\mathrm{N} / \mathrm{mm}^{2}\right)\end{array}$ & $\begin{array}{c}\text { ACS } \\
\left(\mathrm{N} / \mathrm{mm}^{2}\right)\end{array}$ \\
\hline Mx-0 & 50 & 0.86 & $\begin{array}{l}1 \\
2 \\
3\end{array}$ & $\begin{array}{l}16.44 \\
16.00 \\
15.56\end{array}$ & 16.00 & $\begin{array}{l}27.11 \\
26.89 \\
26.22\end{array}$ & 26.74 \\
\hline Mx-1 & 60 & 0.87 & $\begin{array}{l}1 \\
2 \\
3\end{array}$ & $\begin{array}{l}18.22 \\
17.56 \\
17.56\end{array}$ & 17.78 & $\begin{array}{l}29.78 \\
29.56 \\
28.67\end{array}$ & 29.34 \\
\hline
\end{tabular}

$\mathrm{CF}=$ Compaction Factor, $\mathrm{CS}=$ Compressive Strength, ACS = Average Compressive Strength

Similar set of experiments has been conducted for the FST. Table 2 shows the results of compaction factor and slum with 7 and 28 days flexural strength. It can be seen that the flexural strength of concrete containing $10 \%$ waste glass powder is more than that of the reference concrete. The maximum increment in FS was observed with the replacement of $10 \%$ of cement with WGP as compared to without replacement case. For the case of 7 days, the increment in FS was found as $8 \%$, while observed $12 \%$ at the age of 28 days respectively. The results revels similar trends as reported in the research $[1,8]$

Table-3.2 Testing results for Flexural Strength

\begin{tabular}{|c|c|c|c|c|c|c|c|}
\hline \multirow{2}{*}{$\begin{array}{c}\text { Mix } \\
\text { Description }\end{array}$} & \multirow{2}{*}{$\begin{array}{l}\text { Slump } \\
(\mathrm{mm})\end{array}$} & \multirow{2}{*}{$\mathrm{CF}$} & \multirow{2}{*}{ Sample } & \multicolumn{2}{|c|}{ Strength After 7 days } & \multicolumn{2}{|c|}{ Strength After 28 days } \\
\hline & & & & $\mathrm{FS}\left(\mathrm{N} / \mathrm{mm}^{2}\right)$ & $\begin{array}{c}\mathrm{AFS} \\
\left(\mathrm{N} / \mathrm{mm}^{2}\right)\end{array}$ & $\begin{array}{c}\mathrm{FS} \\
\left(\mathrm{N} / \mathrm{mm}^{2}\right)\end{array}$ & $\begin{array}{c}\text { AFS } \\
\left(\mathrm{N} / \mathrm{mm}^{2}\right)\end{array}$ \\
\hline $\begin{array}{r}\text { Mx-0 } \\
\text { (100\% } \\
\text { Cement) }\end{array}$ & 50 & 0.86 & $\begin{array}{l}1 \\
2 \\
3\end{array}$ & $\begin{array}{l}02.83 \\
02.83 \\
02.52\end{array}$ & 02.73 & $\begin{array}{l}03.78 \\
03.46 \\
03.01\end{array}$ & 03.42 \\
\hline $\begin{array}{c}\text { Mx-1 } \\
(10 \% \\
\text { WGP }+90 \% \\
\text { Cement }) \\
\end{array}$ & 60 & 0.87 & $\begin{array}{l}1 \\
2 \\
3\end{array}$ & $\begin{array}{l}03.01 \\
03.01 \\
02.84\end{array}$ & 02.96 & $\begin{array}{l}04.09 \\
03.93 \\
03.46\end{array}$ & 03.83 \\
\hline
\end{tabular}

\section{CONCLUSION}

Compressive Strength Test (CST), Slump Test (ST) and Flexural Strength Test (FST) were conducted to investigate the replacement of cement by using $10 \%$ glass powder for different curing age ( 7 days and 28 days). Results obtained from strength tests of the glass powder based concrete were promising and clearly indicating towards the better economic aspects of glass powder for utilization as the replacement of cement in concrete Following are the conclusions from the study.

$>$ WGP can be used for the increment of strength of concrete

$>$ Replacement of $10 \%$ of WGP improves the Compressive Strength about $11 \%$ after 7 days.

$>$ Replacement of 10\% of WGP improves the Compressive Strength about 9\% after 28 days.

$>$ Improvement in Flexural Strength is also observed with the replacement of cement through WGP

DOI Number: https://doi.org/10.30780/specialissue-ICAASET021/001

pg. 29 
ICAASET-2021, 20-21 May, 2020, K.R. Mangalam University, Gurugram

International Journal of Technical Research \& Science (Special Issue) ISSN No.:2454-2024 (online)

\section{REFERENCES}

[1] Sadiqul G, Rahman M, Kazia N.: Waste glass powder as partial replacement of cement for sustainable concrete practice. Int. J. Sustain. Built. Environ. 6 (2016) 37-44.

[2] Vanjare M, Shriram H.: Experimental Investigation on Self Compacting Concrete Using Glass Powder. Int. J. Eng. Res. Appl. 2 (2012) 1488-1492.

[3] Gunalaan V, Seriganis P.: Performance of Using Waste Glass Powder in Concrete as Replacement of Cement. Am. J. Eng. Res. 2 (2010) 175-181

[4] Vijayakumar G, Vishaliny H, Govindarajulu D.: Studies on Glass Powder as Partial Replacement of Cement in Concrete Production. Int. J. Emerg. Technol. Adv. Eng. 3(2013) 1329-35

[5] IEA, 2007. Tracking Industrial Energy Efficiency and CO2 Emissions. OECD/IEA, 1-321.

[6] Kumarappan N.: Partial Replacement Cement in Concrete Using Waste glass. Int.J. Eng. Res. Technol. 2(2013), 1025-1031.

[7] Detwiler, R., Bhatty, J.I., Bhattacharja, S.: Supplementary Cementing Materials for Use in Blended Cements. Research and Development Bulletin Rd112t, Portland Cement Association, Skokie, Illinois, USA.(1996)

[8] Binici H, Aksogan O, Cagatay I.H., Tokyay M., Emsen E.: The effect of particle size distribution on the properties of blended cements incorporating GGBFS and natural pozzolan (NP) Powder Technol., 177 (2007)140-147

[9] Nassar R, Soroushian P.: Strength and durability of recycled aggregate concrete containing milled glass as partial replacement for cement. Constr. Build. Mater. 29 (2012), 368-377

[10] Rashed A.: Recycled waste glass as fine aggregate replacement in cementations materials based on Portland cement. Constr. Build. Mater. 72 (2014) 340-357.

[11] Chikhalikar M., Tande S.: An Experimental Investigation on Characteristics Properties of Fibre Reinforced Concrete Containing Waste Glass Powder as Pozzolona. 37th Conference on Our World in Concrete and Structures, Singapore, August (2012)

[12] 12.Tamanna .N, Tuladhar R.: Sustainable Use of Recycled Glass Powder as Cement Replacement in Concrete. Open Waste Manage. J. 13 (2020), 1-13. 